\title{
China's Accounting Reform Project - Ten Years Of Progress And Challenges
}

Anne J. Rich (E-mail: anne.rich@quinnipiac.edu), Quinnipiac College

\begin{abstract}
In 1992, China was committed developing a complete set of accounting and auditing standards that would meet international accounting standards. This article summarizes the progress made in the area of accounting, auditing standards and securities regulation from 1992-2002 and highlights some of the challenges that remain for China .
\end{abstract}

\section{Introduction}

¿

n November 2001, the People's Republic of China (China) gained entrance to the World Trade Organization. Those following the history of China can see the seeds of this action were planted in 1979 when China decided to open its doors to foreign investors. As China opened its markets, the government recognized the need to reform its legal and accounting systems and to create a stock exchange. Bringing the Chinese financial reporting standards for business enterprises in line with international standards and developing the profession of public accounting was a necessary condition for reform. In addition to accounting standards, China also needed to establish auditing standards and security regulations. The transformation of the accounting system, from a fund accounting orientation to an accrual based financial reporting system, required substantial effort. Chinese accountants researched international accounting concepts and many of these accounting concepts are integrated into the new Chinese accounting standards. A newly created China Securities Regulatory Commission has authority to prescribe accounting and reporting practices for companies under its jurisdiction while an old arm of the government, the Ministry of Finance, has legislative authority over financial accounting and auditing standards. During the period 1992 - 2002 there have been many new regulations and standards. This paper examines the goals and progress made by China in the accounting, auditing and securities standards since the government began the reformations in 1992. The challenges that remain in these three areas are also presented.

\section{Chinese Accounting Standards: Initial Goals And Early Progress}

China is a country where the accounting is embedded in its laws. There are four levels of legislation over accounting standards. Ding (2000) provides an overview of the current accounting system in China. The structure of the current accounting system in China includes the Accounting Law (1993), the Company Law (1993), the Stock Act (new in 1999) and the CPA Law (1980). The accounting rules for business enterprises were targeted for reform in 1992. The basic financial reporting standards were published in 1993 and initially entitled "Accounting Standards for Business Enterprises". There are also specific accounting specific standards that have been issued to form accounting rules that must be followed by all enterprises.

The objectives of accounting in China as specified in Accounting Standards for Business Enterprises: Basic Standard are as follows:

1. to meet the requirement of national macro-economy control,

2. to meet the needs of all concerned external users to understand an enterprise's financial position and operating results for the purpose of decision making, and

3. to meet the needs of managers to strengthen their internal financial management and administration. 
In order to attract foreign investment at a reasonable cost, China wanted its accounting standards to be accepted by the international business community and wanted this accomplished by 2002. Since 1994, 29 exposure drafts were developed by the Ministry of Finance. The titles of the exposure drafts initially published are summarized in Exhibit I. However, only 16 were actually issued and in force currently. The titles of these standards are shown in Exhibit II. Most of the activity surrounding these 16 standards occurred in 1997 and 1998 and again in 2001 and 2002. According to Lin and Chen (2000), "the government intended to promulgate and implement the complete set of the practical standards in five years"1 from 1997 to 2002. It appears these specific 16 standards were issued because of the needs of investors of listed companies and will be discussed in the section related to securities regulation. However, the standards fall short in terms of meeting investors' needs. Chen, Sun and Wang (2002) examining the impact of the initial seven accounting standards issued in 1998, state that "contrary to the high expectations both in China and abroad, we find that harmonization under the 1998 regulation did not immediately eliminate or significantly reduce the earnings gaps." ${ }^{2}$ Why the remaining accounting standards have not been issued is clearly a disappointment for the accounting profession in China. Lin and Chen suggest the primary reason for postponing standards was the government authorities worried that the new accounting standards would have a negative effect on profits reported by state owned enterprises. Other researchers agree and provide other reasons as well. Ding (2000), for example, identifies several political, economic and social reasons for the lack of harmonization. The researcher highlights the unique aspects of China's macroeconomic considerations as well as resistance to both political and accounting changes. Even if all of the exposure drafts listed in Exhibit 1 are issued, they would not necessarily create the modern accounting system China desired at the early stages of the accounting reform. Many areas are left out of the exposure drafts and most auditors lack professional judgment. While China needs to continue to improve its accounting standards it must also look to the auditing profession to build confidence in the financial reports.

\section{The CPA Profession And Auditing Standards In China}

Ding (2000) reports that the CPA profession existed in China since 1918. Public accountants served the government. The CPA profession was reestablished at the end of 1980. The modern certified public accounting profession is only two decades old. It was created by the government as part of the overall plan to improve financial reporting to investors and creditors. Until the 1980s, auditors in China audited state owned enterprises and were not independent. Public auditors came under the control of the Chinese Association of Certified Public Auditors (CACPA) . At the same time, the Chinese Institute of Certified Public Accountants (CICPA) was established in November 1988 in order to carry out the laws associated with the auditing profession. Turf problems erupted. To solve this problem, in 1995, the CICPA and the Chinese Association of Certified Public Auditors merged. China's accounting standards allows for the revaluation of assets. As a result, there is another profession closely aligned with the CPAs. September 2000, China Asset Evaluation Association, whose membership deals with asset revaluations, joined with the CICPA although the CPA profession and the Certified Evaluator profession maintain their respective independent existence. The CICPA, continued to grow in statue when in September 2002, they became associated with the Certified Tax Consultant profession although they kept their management independent. Another tax organization, The China Institute of Certified Tax Consultants (CICTC) also joined the CICPA as a community member.

Similar to the development of accounting standards, the government regulates auditing standards. There are four major laws: (1) The PRC CPA Law, (2)The Accounting Law, (3), The Company Law. and (4) Provisional Measures. Chen Yu Gui, Executive Director of the CICPA, provided this overview of the four major laws in a speech in March $2003^{3}$ :

The PRC CPA Law. Promulgated in October 1993, this law defines the legal status of CPAs in the socialist market economy, and lays down comprehensive regulations on the professional management system, CPA exams and registration, CPA business scope and practicing standards, accounting firms, CPA institutes and legal liabilities.

The new Accounting Law. This law was promulgated in 1985 and revised in October 1999. The new Accounting Law stipulates on accounting verification, accounting supervision, accounting bodies and accounting 
personnel. Such accounting bodies and accounting personnel refer to accounting departments and their staff within enterprises rather than accounting firms and CPAs. Meanwhile, provisions on CPAs are added to the new law, which further clarify the monitoring role of CPAs in conducting public audit and the accounting responsibility of their audit clients.

The Company Law, the Enterprise Law, the Rules on Transformation of Operating Mechanism for Industrial Enterprises of All People Ownership, and the Securities Law lay down their respective provisions on the audit status, business scope and liabilities of CPAs.

The Provisional Measures for CPA Audit of Annual Accounting Statements Prepared by State-owned Enterprises. According to these provisional measures, starting from 1998, with a few exceptional industries (and enterprises), the system of fiscal review and approval is no longer to be applied to SOE annual accounting statements. Instead, such statements are commissioned to CPAs for audit purpose.

Chen Yu Gui also highlighted the following accomplishments of the CICPA:

The National CPA Exams were first held in 1991 and have been carried out once every year since 1993. According to the CPA Law, since 1994 the PRC National CPA. Over the recent years, there are over 600,000 candidates registered for the exams each year. Such exams have been held 11 times with nearly 80,000 people passed all the required exams. There are over 400 overseas candidates passing the exams and qualifying themselves as CICPA members.

Continuously improved professional standards. Since 1995, 46 independent audit standards have been prepared and issued giving rise to a preliminary system of independent audit standards that are consistent with international audit standards in all material aspects. At present, the CICPA is formulating, supplementing and improving new standards that are pertinent to audit of the securities market.

Emphasized and reinforced continuous education and training of human resources. In 1996, the CICPA established its system of professional continuous education and training. In recent years, annual training volume exceeds 70,000 person/time. The government has set up the National Accounting Institute in Beijing and the Shanghai Accounting Institute with the Xiamen already in progress. Recently, the CICPA has experimented with remote professional training and education making use of the resources and facilities enjoyed by the two institutes. In addition, since 1995, 23 higher education institutes have designed their CPA major to specialize in training CPA professionals.

Reformed the management system for accounting firms. Initially, CPA firms attached themselves to specific government departments. Firms were criticized for not being independent. China was under pressure to conform to international practices. Accounting firms now must be independent and practice self-management, self-development and self-discipline.

Achieved distinctive results in international exchanges and market liberalization. Since the beginning of the 1980s, China has gradually liberalized its accounting service market to the outside world. Such liberalization has taken two forms: (1) Permitting overseas accounting firms to set up their representative offices, and/or member firms in the PRC and apply for temporary practice permit and (2) permitting foreign citizens and residents of Hong Kong, Macao and Taiwan to sit in the PRC National CPA Exams and apply for practicing qualifications. Thus, Chinese accounting service market is open up on all fronts. The CICPA has joined the Asia-Pacific Confederation of Accountants (CAPA) and the International Federation of Accountants (IFA). At present, the CICPA has already established formal exchange relationship with 26 professional organizations of accountants in 16 countries and regions.

The 45 auditing standards represent a substantial effort to bring auditing standards in line with international expectations. However, auditing standards must be interpreted and implemented by CPAs. China does not have 
enough qualified CPAs. When the accounting profession was created, China had hoped to have 100,000 CPAs within the first 10 years. Currently, China has 56,900 practicing CPAs and over 4,500 accounting firms. Ding (2000) reported that in 1997 there were 58,000 practicing CPAs and 6,700 firms. Thus we see the number of practicing CPAs as well as the number of accounting firms has declined. Firms merged in order to be more competitive. Perhaps some of the older CPAs, originally grandfathered into the profession, no longer practice. The low number of qualified CPAs is clearly a disappointment and slows the pace of accounting reforms.

While there has been significant progress in the development of auditing standards Cooper et al (2000)) identify the following issues still exist in the auditing profession: professional competence, independence, ethical standards and auditing practice. The lack of professional competence comes partly as a result of so many CPAS being grandfathered into the profession. The lack of independence stems from the problems of CPA firms being economically and politically tied to government agencies. While the new rules require independence, old habits and connections are difficult to throw away. The researcher reports their previous finding found in a Ministry of Finance practice review in 1998 that resulted in the revocation of 300 CPA certificates and 2,000 warnings or punishments with certificate suspensions as well as over 1,500 firms fined or penalized. Concerning problems in audit practice, Cooper et al state "A number of major financial scandals erupted in the early 1990s and exposed publicly the ethical and quality problems that has existed in accounting and audit firms for some time. The most notorious case was the "Great Wall fundraising" scandal, reported in 1993 (Zheng and Chen, 1993) In this case, the Great Wall Electrical Engineering Science and Technology Com was found to have raised one billion reminbi, illegally, though coupon securities that involved embezzlement, in complicity with the Zhongcheng Accounting Firm, which issued fraudulent certificates in respect of how the fund were used." ${ }^{4}$

Frauds have occurred throughout this period from the early 1990s through today. Lipsher writes ${ }^{5}$ : "Other experts say the main problem with China's accounting profession is not the standards themselves but the way they are implemented. They caution against loose supervision and a lenient punishment mechanism towards accounting professionals in China." He also says: "The February 2002 issue of the monthly The Chinese Accountant published by the Chinese Institute of Certified Public Accountants featured two articles: "Why Are CPAs Often Embroiled in the Accounting Fraud of Listed Companies?" and "Ideas on Establishing and Perfecting the Regulation System of the CPA Profession". However, Lipsher cites the profession of accounting as well as the Ministry of Finance have made this subject a priority and concludes it is 'too early' to say how and what will develop, specific policies and enforcement practices will be implemented on an ongoing basis.

\section{The Development Of Securities Regulations In China}

Similar to the U.S.'s Securities and Exchange Commission, the China Securities Regulatory Commission (CSRC) has the authority to prescribed accounting and reporting practices for companies under its jurisdiction. The CSRC must follow the rules on information disclosure that are promulgated by the following legislative bodies:

1. The Company Act, the Security Act and the Criminal Law issued by the National Congress

2. The Statutes of Stock Issuance and Exchange issued by the State Council

3. Disclosure rules issued by the CSRC

4. Rules on listed companies issued by the Stock Exchange.

The CSRC issues four types of disclosure rules:

1. Statements of Form and Contents of Information Disclosure - to date there are 11 statements

2. Rules on disclosure practice

3. Financial Reporting Releases - special requirements for IPO, there are special rules for banks, securities companies, insurance companies and real estate companies, requirements for quarterly reports, calculations and presentation of ROE and EPS

4. Staff Accounting Bulletins 
As a result of these disclosure requirements, Chinese listed firms are becoming more transparent. But there are still many problems. One of the biggest challenges for the CRSC had been the dissemination of information. Prior to 1992, local newspapers were the major medium for the dissemination of information. However, the newspapers were under the control of local governments and the central bank. Beginning in 1992, specific newspapers have been designated by the CSRC to provide more independent reporting of news relating to securities. There are also reliable internet sites.

Another challenge deals with financial fraud. While financial frauds occur all over the world, China is particularly sensitive to this problem. Companies must maintain a certain return on investment in order to retaining their listings on the stock exchanges. During 2002, 105 official notices were sent out to listed companies indicating deficiencies in reporting. Nineteen companies were publicly censured during 2002. Some of their biggest problems are related party transactions. Thus, China's made the decision to issue the relation party accounting standard as the first accounting standards. Other big problems are created by the large number of non-monetary transactions. Also, China allows for the revaluation of assets. The new accounting standards were issued to address these problems. The CRSC hopes to revise their rules concerning the delisting of listed companies in order to develop clearer rules as well as issue rules to improve the quality of financial reports.

A third challenge is the quality of auditors. Chen, Sun and Wang (2002) ${ }^{6}$ found that "Big 5 auditors seem effective in reducing earnings gap" indicating that there are significant differences in the audits of large international firms as compared to local Chinese firms. Even the largest firms are under attack. In a recent newspaper article, International Accounting Bulletin, April 04, 2003 reported KPMG China is believed to be the first Big Four auditor to face the Chinese courts over falsified financial information. Audit client Jinzhou Port Co, a Shanghai-listed company, is being sued by one of its shareholders for civil compensation. The lawsuit was filed by the Shenyang Intermediate People's Court in North-East China's Liaoning Province in February.; The Ministry of Finance first noticed accounting irregularities at the company during an audit in 2001 and it revealed details of inflated revenues and assets. Last year, Jinzhou issued revised financial statements of 367.18 million yuan (\$44.3 million) from 1996 to 2000 . The company was fined 100,000 yuan by the ministry for this fraudulent booking. The Jinzhou case joins the 900 similar offences that have been accepted by the Chinese courts since January 2002, most of which are still under review.

Lipsher $^{7}$ writes: "There is a growing perception that Chinese financial statements are not worth the paper that they are written upon; that something must be done to rectify this situation. Regardless of whether this is a problem of standards or application of standards/enforcement of proper punishment for lack of adherence to such standards, answers to these problems must be found for these are major problems in China. If China is to continue getting what it wants for its share of the international investment dollar, then it must develop meaningful financial reporting."

\section{Conclusion}

The accounting reforms in China during the period 1992 - 2002 have made significant progress. A conceptual framework along with sixteen accounting standards have been issued. The accounting profession is now composed of more then 56,000 who have to follow 45 auditing standards. The regulations of securities now require important disclosures to provide investors with relevant information. However, there needs to be more accounting standards, interpreted by better trained certified public accountants, and regulated better by the Chinese Securities Regulatory Commission. China has a long way to go in order to restore investor confidence in financial statements but seems committed to accomplish this goal.

The author acknowledges the assistance of Liu Da Wei, graduate student at Quinnipiac University, who ably translated into English documents posted on Chinese web sites. 


\section{Footnotes}

1. Z. Jun Lin and Feng Chen, "Asian Financial Crisis and Accounting Reforms in China", Managerial Finance, 2000, p 64.

2. Shimin Chen, Zheng Sun and Yuefang Wang, "Evidence from China on Whether Harmonized Accounting Standards Harmonize Accounting Practices", Accounting Horizons, Sept. 2002, p.195.

3. A speech given by Dr. Chen on March 17, 2003 to the People-to-People delegation in Beijing, China.

4. Barry J. Cooper, Lynne Chow, and Tang Yun Wei, "The Development of Auditing Standards and the Certified Public Accounting Profession in China", Managerial Auditing Journal, 2002, p. 387.

5. Laurence E. Lipsher, "The New Chinese Accounting Standards, Regulations and Enforcement”, May 2002, found at www.prctaxman.cn on September 3, 2003.

6. Shimin Chen, Zheng Sun and Yuefang Wang, "Evidence from China on Whether Harmonized Accounting Standards Harmonize Accounting Practices”, Accounting Horizons, Sept. 2002, p.195.

7. Laurence E. Lipsher, "The New Chinese Accounting Standards, Regulations and Enforcement”, May 2002, found at www.prctaxman.cn on September 3, 2003.

\section{References}

1. Chen, S., Sun, Z, and Wang, Y, "Evidence form China on Whether Harmonized Accounting Standards Harmonize Accounting Practices", Accounting Horizons, September 2002.

2. Chen Yu Gui, Executive Director, Chinese Institute of Certified Public Accountants, Speech delivered on March 17, 2003.

3. Chow, Lynne Min-ying, Chau, Gerald, and Gray. Sidney J., "Accounting Reforms in China: Cultural Constraints on Implementation and Development", Accounting and Business Research, 1995, Vol 26, No. 1, pp. 29-49.

4. Cooper, Barry J., Lynne Chow, and Tang Yun Wei, "The Development of Auditing Standards and the Certified Public Accounting Profession in China", Managerial Auditing Journal, Vol 17 2002, pp. 383389.

5. Davidson, R., A. Gelardi, and F. Li, Analysis of the Conceptual Framework of China's New Accounting System, 1996, Accounting Horizons, Vol 10, No. 1, pp. 58-74.

6. DaCosta, Maris Manuela Neveda and Foo, Jennifer Ping Ngoh, China's financial System: Two Decades of Gradual Reforms", Managerial Finance, 2002, Vol 28 pg. 3- 19.

7. Ding, Yuan, "Harmonization trends in Chinese accounting and Remaining Problems", 2000, Managerial Finance, Vol 26, pgs 31-40.

8. Goligoski, R. "The Impact of International Accounting Standards in the People's Republic of China", December 1995, IASC Insight, The Newsletter of the International Accounting Standards Committee, London, England.

9. Lin, A. Jun and Feng Chen, "Asian Financial Crisis and Accounting Reforms in China", Managerial Finance, 2000, Vol. 26 pp. 63-80.

10. Lipsher, Laurence, "The New Chinese Accounting Standards: Regulations and Enforcement”, May 2002, at www. Prctaxman.com.cn September 3,m, 2003.

11. Winkle, G., H.Huss and C. XiZhu, "Accounting Standards in the People's Republic of China: Responding to Economic Reforms", 1994, Accounting Horizons, Vol 8, No. 3 pp. 48 - 57.

12. Xiao, Z. , David Young, J. Dyson and A. Pan, "Development of Accounting Standards and Conceptual Framework in China", 1995, Advances in International Accounting, Vol. 8, pp. 177-200.

13. Xiang, Bing, "Institutional Factors Influencing China's Accounting Reforms and Standards", Accounting Horizons, Vol 12, No 2, June 1998. 
Exhibit I

Originally Proposed Detailed Accounting Standards

1. Accounting for payables

2. Accounting for receivables

3. Inventory

4. Investments

5. Capitalized borrowing costs

6. Form of the balance sheet

7. Form of the income statement

8. Fixed assets

9. Intangible assets

10. Research and development

11 Long-term contracts

12. Cash flow statements

13. Basic banking business

14. Owners' equity

15. Foreign exchange transactions

16. Revenue

17. Accounting for income tax

18. Consolidated financial statements

19. Accounting policies and changes in accounting policies and estimates

20. Subsequent events

21. Employee benefits

22. Contingencies and commitments

23. Government grants and donations

24. Liquidation accounting

25. Commodity Futures

26. Leases

27. Business combinations

28. Non-monetary transactions

29. Disclosure of related parties and related party transactions 
Exhibit II:

China's Accounting Standards Currently In Effect

\begin{tabular}{|c|c|c|c|}
\hline Standard No. & Description & Date Effective & $\begin{array}{l}\text { Types Of Entity } \\
\text { This Is Applicable For: }\end{array}$ \\
\hline 1 & $\begin{array}{l}\text { Related Party } \\
\text { Transactions }\end{array}$ & January 1997 & Listed Companies \\
\hline 2 & Cash Flow Statement & $\begin{array}{l}\text { Revision effective } \\
\text { January } 2001\end{array}$ & All entities \\
\hline 3 & Subsequent Events & January 1998 & Listed Companies \\
\hline 4 & $\begin{array}{l}\text { Debt Restructuring } \\
\text { (Substantial revision) }\end{array}$ & $\begin{array}{l}\text { Revision effective } \\
\text { January } 2001\end{array}$ & All entities \\
\hline 5 & Revenue & January 1999 & Listed Companies \\
\hline 6 & Investments & $\begin{array}{l}\text { Revision effective } \\
\text { January } 2001\end{array}$ & Joint Stock Companies/JVs \\
\hline 7 & Construction Contracts & January 1999 & Listed Companies \\
\hline 8 & Accounting Policies & $\begin{array}{l}\text { Revision effective } \\
\text { January } 2001\end{array}$ & All entities \\
\hline 9 & $\begin{array}{l}\text { Non-monetary Transactions } \\
\text { (Substantial revision) }\end{array}$ & $\begin{array}{l}\text { Revision effective } \\
\text { January } 2001\end{array}$ & All entities \\
\hline 10 & Contingencies & July 2000 & All entities \\
\hline 11 & Intangible Assets & January 2001 & Joint Stock Companies/JVs \\
\hline 12 & Borrowing Costs & January 2001 & All entities \\
\hline 13 & Leases & January 2001 & All entities \\
\hline 14 & Interim Reporting & January 2002 & Listed Companies \\
\hline 15 & Inventories & January 2002 & Joint Stock Companies/JVs \\
\hline 16 & Fixed Assets & January 2002 & Joint Stock Companies/JVs \\
\hline
\end{tabular}

Source: Laurence E. Lipsher, "The New Chinese Accounting Standards, Regulations and Enforcement”, May 2002 www.prctaxman.com.cn, found on September 3, 2003. 